RESEARCH PAPER

\title{
Characterization of dihydrolipoamide dehydrogenase from the mitochondria of Helicoverpa armigera, a pest resistant to insecticides
}

\author{
S. Md. AKBAR, ${ }^{1,3}$ S. K. JAYALAKSHMI, ${ }^{2}$ H. C. SHARMA ${ }^{3}$ and K. SREERAMULU ${ }^{1}$ \\ 1 Department of Biochemistry, Gulbarga University, Gulbarga, India \\ 2 Agriculture Research Station, University of Agricultural Sciences, Gulbarga, India \\ 3 International Crops Research Institute for the Semi-Arid Tropics (ICRISAT), Andhra Pradesh, India
}

\author{
Correspondence \\ K. Sreeramulu, Department of \\ Biochemistry, Gulbarga University, \\ Gulbarga 585106, Karnataka, India. Email: \\ ksramu@rediffmail.com
}

Received 18 June 2011; accepted 7 September 2011.

doi: $10.1111 / j .1748-5967.2011 .00346 . x$

\begin{abstract}
Dihydrolipoamide dehydrogenase (DHLDH) was isolated from the mitochondria of Helicoverpa armigera, a destructive pest which has developed resistance to commonly used insecticides. The flavoenzyme was purified 17.98 -fold to homogeneity with an overall yield of $10.53 \%$ by employing ammonium sulfate precipitation, hydroxylapatite chromatography and CM-Sephadex chromatography. The purified enzyme exhibited the specific activity of $18.7 \mathrm{U} / \mathrm{mg}$ and was characterized as a dimer with a subunit mass of $66 \mathrm{kDa}$. The enzyme showed specificity for nicotinamide adenine dinucleotide - hydrogen (NADH) and lipoamide, as substrates, with Michaelis-Menten constants $\left(\mathrm{K}_{\mathrm{m}}\right)$ of $0.083 \mathrm{mmol} / \mathrm{L}$ and $0.4 \mathrm{mmol} / \mathrm{L}$, respectively. The reduction reaction of lipoamide by the enzyme could be explained by ping-pong mechanism. The spectra of DHLDH showed the maximum absorbance at $420 \mathrm{~nm}, 455 \mathrm{~nm}$ and $475 \mathrm{~nm}$. The enzyme activity was strongly inhibited by mercurial and arsenical compounds. The N-terminal sequence of Ha-DHLDH showed homology with those of mammalian and arthropod DHLDH. Since H. armigera has developed high levels of resistance to commonly used insecticides, biochemical properties of the metabolic enzymes such as DHLDH, could be helpful to develop insecticidal molecules for the control of H. armigera, with a different mode of action.
\end{abstract}

Key words: arsenical compounds, dihydrolipomide dehydrogenase, Helicoverpa armigera, mitochondria.

\section{Introduction}

The mitochondrial enzyme, dihydrolipoamide dehydrogenase (DHLDH) (E.C.1.8.1.4) belongs to the group of flavincontaining pyridine nucleotide disulfide oxidoreductases (Huo et al. 2010) such as trypanothione reductase, glutathione reductase, thioredoxin reductase and mercuric reductase. DHLDH is a component of multienzyme complexes such as pyruvate dehydrogenase (PDH), $\alpha$-ketoglutarate dehydrogenase $(\alpha-\mathrm{KGDH})$ and branched chain ketoacid dehydrogenase (BCKADH). PDH is involved in irreversibly committing pyruvate from glycolysis to the Krebs cycle, whereas $\alpha-\mathrm{KGDH}$ and BCKADH catalyze decarboxylation of $\alpha$-ketoglutarate and regulate oxidation of branched chain ketoacids, respectively (Yan et al. 2008).

These multienzyme complexes consist of three subunits $\left(E_{1}, E_{2}\right.$ and $\left.E_{3}\right)$ with analogous functions. Subunit $E_{1}$ is the decorboxylase dehydrogenase, $E_{2}$ is transacetylase containing covalently bound lipoic acid, while subunit $\mathrm{E}_{3}$ is the DHLDH, which reoxidises the dihydrolipoyl moiety linked to a specific lysine side chain of subunit $\mathrm{E}_{2}$ and regenerates lipoamide for the latter part of the $\mathrm{E}_{1}$ reaction (Pullikuth \& 
Gill 1997). Subunits $E_{1}$ and $E_{2}$ are substrate-specific and differ in each complex, whereas $\mathrm{E}_{3}$ is identical in all the three complexes, catalyzing the reversible reaction: lipoamide + nicotinamide adenine dinucleotide - hydrogen $(\mathrm{NADH})+\mathrm{H}^{+}$ $\leftrightarrow$ dihydrolipoamide + nicotinamide adenine dinucleotide (oxidized) $(\mathrm{NAD})^{+}$(Lohrer \& Krauth-Siegel 1990). All DHLDHs are stable homodimers, each monomer possessing a noncovalently but tightly bound flavin adenine dinucleotide (FAD), a transiently bound NADH or NAD ${ }^{+}$molecule, and two redox-active cysteine residues (Brautigam et al. 2005). Apart from its role in $\alpha$-ketoacid dehydrogenase complexes, $\mathrm{E}_{3}$ exhibits a number of additional functional capacities. DHLDH acts as a diaphorase (Patel et al. 1995), is also capable of scavenging nitric oxide (Igamberdiev et al. 2004) and can serve as an antioxidant by protecting other proteins against oxidative inactivation (Korotchkina et al. 2001). DHLDH can also act as a proteolytic enzyme when the stability of the enzyme is altered (Babady et al. 2007).

Previously, DHLDH of human (Babady et al. 2007), Mycobacterium tuberculosis (Rajashankar et al. 2005), silk worm (Huo et al. 2010) and Manduca sexta (Pullikuth \& Gill 1997) were cloned and expressed in Escherichia coli for structural and functional studies. However, DHLDH has been characterized only from a limited number of insect species. Despite the similarities in metabolism between vertebrates and arthropods, insects specifically possess some features as additional requisite reactions, superimposed on normal metabolic pathways as a possible adaptive mechanism (Pullikuth \& Gill 1997), such as utilization of proline for energy generation during flight, use of trehalose as a major blood sugar and so on. Since insects represent the most abundant and diverse group of organisms in any phylum, their number and diversity far exceeding species in all other phyla combined (Novotny et al. 2002), they are interesting candidates to study evolutionary, genetic and biochemical properties of multienzyme complexes.

Helicoverpa armigera (Noctuidae: Lepidoptera), commonly called cotton bollworm or legume pod borer, is one of the major pests of cotton, pulses, cereals, vegetables, fruits and forest trees (Sharma 2005). It has developed high levels of resistance to several insecticides such as endosulfan, methomyl, monocrotophos, quinalphos, chlorpyriphos, fenvalerate and cypermethrin (Chaturvedi 2007), and also to Bacillus thuringenisis Cry1Ac toxin (Gunning et al. 2005). Because of the amenability of insects to adapt to environments and develop resistance to several insecticides, biochemical properties of the enzymes involved in metabolism, such as DHLDH, could be helpful to develop insecticidal molecules for the control of $H$. armigera, with a different mode of action. In the present study, we report the characterization of purified DHLDH from the mitochondria of $H$. armigera, its $\mathrm{N}$-terminal sequence analysis and inhibition of enzyme activity by arsenical compounds.

\section{Materials and methods}

\section{Chemicals}

$\alpha$-Lipoamide, $\quad$ CM-Sephadex, $3[$ (3-cholamidopropyl) dimethylammonio]-propanesulfonic acid (CHAPS), hydroxylapatite, NADH, sodium arsenite and melarsoprol were purchased from Sigma Aldrich (Mumbai, India). Trisbase, pyruvate and 5,5 $5^{1}$-dithio-bis(2-nitro benzoic acid) were purchased from Himedia (Mumbai, India) while the other chemicals were of analytical grade.

\section{Insects}

Cypermethrin-resistant (60-fold) population of $H$. armigera was supplied by Dr S.S. Udikeri, Agriculture Research Station, UAS, Dharwad, Karnataka, India. The larvae were washed in chilled distilled water, their gut contents removed and body membranes taken for isolation of DHLDH.

\section{Isolation of enzyme}

For the isolation of DHLDH, the mitochondria were isolated from body membranes of fourth and fifth instar larvae of H. armigera $(\sim 23 \mathrm{~g})$ according to the modified method of Yan et al. (2008). This entailed gently homogenizing the body membranes of the larvae in isolation buffer containing $0.25 \mathrm{M}$ sucrose, $1 \mathrm{mmol} / \mathrm{L}$ ethylendiametetraacetic acid (EDTA) and $50 \mathrm{mmol} / \mathrm{L}$ Tris-HCl, $\mathrm{pH}$ 7.4. The homogenate was centrifuged at $800 \times g$ for $5 \mathrm{~min}$, and the supernatant was centrifuged at $12000 \times g$ for $10 \mathrm{~min}$. The pellet containing mitochondria was suspended in $50 \mathrm{mmol} / \mathrm{L}$ Tris- $\mathrm{HCl}$ buffer, $\mathrm{pH} 7.4$, containing $1 \mathrm{mmol} / \mathrm{L}$ EDTA and $1 \%$ CHAPS and kept stirring at $4{ }^{\circ} \mathrm{C}$ overnight. The extract was centrifuged at $15000 \times g$ for $30 \mathrm{~min}$, and the supernatant was used as a source of DHLDH.

\section{Enzyme assays}

The DHLDH activity was assayed spectrophotometrically in $50 \mathrm{mmol} / \mathrm{L}$ Tris- $\mathrm{HCl}$ buffer, $\mathrm{pH} 7.4$, containing $1 \mathrm{mmol} / \mathrm{L}$ EDTA, $1 \mathrm{mmol} / \mathrm{L}$ dithioerythritol, $0.025 \mathrm{mmol} / \mathrm{L} \mathrm{NADH}$ and $0.5 \mathrm{mmol} / \mathrm{L}$ lipoamide, in a total reaction volume of $1 \mathrm{~mL}$ in presence of purified protein at $30^{\circ} \mathrm{C}$ (Huo et al. 2010). The reaction was started by addition of lipoamide, and NADH oxidation was measured as change in absorbance at $340 \mathrm{~nm}$ over time. The PDH complex activity was measured spectrophotometrically at $30^{\circ} \mathrm{C}$ according to Hein and Steinbüchel (1994). Reduction of NAD was measured at $340 \mathrm{~nm}$ and the reaction started with $1.5 \mathrm{mmol} / \mathrm{L}$ pyruvate. One unit of enzyme activity was expressed as $\mu$ moles of $\mathrm{NADH}$ consumed or produced per minute at $30^{\circ} \mathrm{C}$. Protein concentration was determined by Lowry's method (1951). 


\section{Purification of DHLDH}

To purify DHLDH, ammonium sulfate was added to $50 \mathrm{~mL}$ of crude extract (1100 mg of protein) to give $40 \%$ saturation. The solution was kept for overnight stirring at $4{ }^{\circ} \mathrm{C}$, and the precipitate was removed by centrifugation for $30 \mathrm{~min}$ at $10000 \times g$, and the supernatant was brought to $60 \%$ ammonium sulfate saturation. After overnight stirring at $4{ }^{\circ} \mathrm{C}$, saltprecipitated proteins were collected by centrifugation for $30 \mathrm{~min}$ at $10000 \times g$, and dissolved in buffer A $(50 \mathrm{mmol} / \mathrm{L}$ Tris- $\mathrm{HCl}$ buffer, $\mathrm{pH}$ 7.4, containing $1 \mathrm{mmol} / \mathrm{L}$ EDTA, $1 \mathrm{mmol} / \mathrm{L}$ dithioerythritol), and dialyzed for $18 \mathrm{~h}$ against the preceding buffer at $4^{\circ} \mathrm{C}$. This pool was applied to a hydroxylapatite column $(2 \times 10 \mathrm{~cm})$ previously equilibrated with buffer A. After the column was washed with $100 \mathrm{~mL}$ of the same buffer, proteins were eluted with a step gradient of

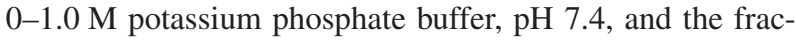
tions were collected each of $3 \mathrm{~mL}$. DHLDH activity was eluted at $0.4 \mathrm{M}$ and $0.5 \mathrm{M}$ phosphate buffer fractions, and the active fractions were pooled, concentrated and dialyzed against buffer B (50 mmol/L phosphate buffer, $\mathrm{pH} 7.4$, containing $1 \mathrm{mmol} / \mathrm{L}$ EDTA and $1 \mathrm{mmol} / \mathrm{L}$ dithioerythritol), and applied to a column of CM-Sephadex $(2 \times 10 \mathrm{~cm})$ previously equilibrated with the preceding buffer. After the column was washed with $40 \mathrm{~mL}$ of buffer $\mathrm{B}$, proteins were eluted from the column with a step gradient of $0-1 \mathrm{M} \mathrm{NaCl}$ and fractions of $2 \mathrm{~mL}$ each were collected. DHLDH activity was eluted at $0.5 \mathrm{M}$ and 0.6 M NaCl. Fractions containing DHLDH activity were pooled, concentrated using Viva cell 250 (molecular weight [MW] 50000 ) to a final volume of $2.5 \mathrm{~mL}$, and dialyzed against buffer B. DHLDH in the purified preparation was tested for homogeneity by sodium dodecylsulfate polyacrylamide gel electrophoresis (SDS-PAGE) (Laemmli 1970).

\section{Electrophoresis}

The molecular weight of the protein under denaturing conditions was determined by $10 \%$ SDS-PAGE (Laemmli 1970). Native molecular weight of the protein was determined by native PAGE, in polyacrylamide gel gradient formed from $5 \%$ to $15 \%$ using Sigma molecular weight markers in the range of 29 to $205 \mathrm{kDa}$ (Margolis \& Kenrick 1967). DHLDH activity was detected by incubating the gel in a reaction mixture containing $2 \mathrm{mmol} / \mathrm{L}$ lipoamide, $0.4 \mathrm{mmol} / \mathrm{L} \quad \mathrm{NADH}, \quad 0.5 \mathrm{mmol} / \mathrm{L} \quad 5,5^{1}$-dithio-bis(2-nitro benzoic acid) and $1 \mathrm{mmol} / \mathrm{L}$ EDTA in $50 \mathrm{mmol} / \mathrm{L}$ potassium phosphate buffer, $\mathrm{pH} 7.4$, at $37^{\circ} \mathrm{C}$, until yellow bands appeared (Dietrichs \& Andreesen 1990).

\section{Kinetic studies and substrate specificity}

Kinetic studies were carried out in $50 \mathrm{mmol} / \mathrm{L}$ phosphate buffer, pH 7.4, containing $1 \mathrm{mmol} / \mathrm{L}$ EDTA and $1 \mathrm{mmol} / \mathrm{L}$ dithioerythritol in a total reaction volume of $1 \mathrm{~mL}$ at $30^{\circ} \mathrm{C}$. NADH concentration varied from $0.05 \mathrm{mmol} / \mathrm{L}$ to $0.4 \mathrm{mmol} / \mathrm{L}$ at $2.5 \mathrm{mmol} / \mathrm{L}$ lipoamide, for determination of Michaelis-Menten constants $\left(\mathrm{K}_{\mathrm{m}}\right)$ of $\mathrm{NADH}$ and lipoamide concentration varied from $0.5 \mathrm{mmol} / \mathrm{L}$ to $4 \mathrm{mmol} / \mathrm{L}$ at $0.25 \mathrm{mmol} / \mathrm{L} \mathrm{NADH}$, for determination of $\mathrm{K}_{\mathrm{m}}$ of lipoamide. Substrate specificity was tested using both the reduced pyridine nucleotides, NADH and Nicotinamide adenine dinucleotide phosphate - hydrogen (reduced) (NADPH) for the reduction of lipoamide. Double-reciprocal plots were drawn to determine the mechanism of enzyme catalyzed reaction in the direction of oxidation of NADH with varying NADH concentrations at fixed lipoamide concentrations of $1 \mathrm{mmol} / \mathrm{L}, 1.5 \mathrm{mmol} / \mathrm{L}$ and $2 \mathrm{mmol} / \mathrm{L}$.

\section{Influence of $\mathrm{pH}$, temperature and metal ions}

Influence of $\mathrm{pH}$ on the activity of DHLDH was studied in the above-mentioned reaction mixture at different $\mathrm{pH}$ values ranging 4-10. Acetate buffer, Tris- $\mathrm{HCl}$ and bicarbonate buffer were used for acidic, neutral and basic $\mathrm{pH}$ of the reaction mixture, respectively. The enzyme was incubated at different temperatures ranging $20-80^{\circ} \mathrm{C}$ for $15 \mathrm{~min}$, to determine the effect of temperature on enzyme activity. Metal ions such as $\mathrm{Na}, \mathrm{Mg}, \mathrm{K}, \mathrm{Ca}, \mathrm{Mn}, \mathrm{Fe}, \mathrm{Cd}, \mathrm{Ag}, \mathrm{Zn}, \mathrm{Co}, \mathrm{Pb}, \mathrm{Cu}$, $\mathrm{Hg}$, arsenite and melarsoprol at $1 \mathrm{mmol} / \mathrm{L}$ concentrations were incubated with the enzyme for $15 \mathrm{~min}$ at room temperature to determine the effect of different metal ions on the catalytic activity of the enzyme.

\section{Identification of coenzyme}

The purified enzyme was denatured at $100^{\circ} \mathrm{C}$ in dark to liberate the bound flavin and centrifuged at $15000 \times g$ for $15 \mathrm{~min}$. The released flavin was analyzed by thin layer chromatography (Dietrichs \& Andreesen 1990). Protein spectra were obtained by Schimadzu spectrophotometer (Shimane Shimadzu Corporation, Shimane, Japan) keeping $50 \mathrm{mmol} / \mathrm{L}$ phosphate buffer, $\mathrm{pH} 7.4$, as reference.

\section{$\mathrm{N}$-terminal sequencing}

For determination of N-terminal sequence, purified DHLDH protein was subjected to SDS-PAGE, then the protein was transferred to polyvinylidenedifluoride membrane, and the membrane was stained with Coomassie blue R250. The enzyme was detected in gel by activity staining (Dietrichs \& Andreesen 1990); areas of DHLDH from the membrane were excised and sent for sequence analysis using Edman degradation based Procise protein sequencing system at HSC Advanced Protein Technology Center, Department of Structural Biology and Biochemistry, Toronto, Canada. The $\mathrm{N}$-terminal sequence was blasted with mammal and arthropod DHLDH sequences using the NCBI website (http:// www.ncbi.nlm.nih.gov). 


\section{Results}

\section{Purification of DHLDH}

Figures 1 and 2 show the elution profile of DHLDH of H. armigera from hydroxylapetite and CM-Sephadex, respectively. From $1100 \mathrm{mg}$ of total protein, $4 \mathrm{mg}$ of enzyme was obtained with 17.98-fold-increased specific activity and $10.53 \%$ recovery. Specific activity of purified enzyme was 18.7 U/mg of protein (Table 1).

\section{Molecular weight of DHLDH}

The subunit molecular weight of DHLDH was estimated to be $66 \mathrm{kDa}$. The native molecular weight of the protein was determined to be $128 \mathrm{kDa}$, suggesting that the protein existed as a dimer (Fig. 3).

\section{Kinetic studies and substrate specificity}

The velocity of NADH-dependent reduction of lipoamide showed a hyperbolic dependence on the NADH and

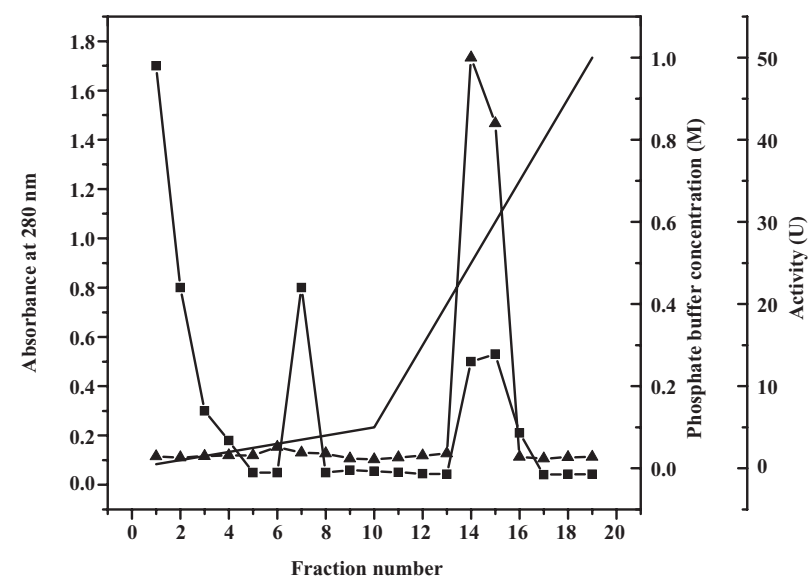

Figure 1 Elution profile for the protein and dihydrolipoamide dehydrogenase activity on hydroxylapatite column. Protein $(\boldsymbol{\square})$, enzyme activity $(\mathbf{\Lambda})$, phosphate buffer concentration $(-)$. lipoamide concentration (data not shown). Estimated $\mathrm{K}_{\mathrm{m}}$ were $0.083 \mathrm{mmol} / \mathrm{L}$ for $\mathrm{NADH}$ and $0.4 \mathrm{mmol} / \mathrm{L}$ for lipoamide, maximum velocity $\left(\mathrm{V}_{\max }\right)$ of $61.25 \mathrm{U}$ was observed in both the cases, that is, with varying concentrations of lipoamide and NADH. Substrate specificity tested in the direction of oxidation of reduced pyridine nucleotides indicated that the enzyme was highly specific to NADH as a coenzyme, and did not use NADPH. Double reciprocal plots drawn for the enzyme activity yielded a series of parallel lines, which fitted the ping-pong mechanism of catalysis (Fig. 4).

\section{Influence of $\mathrm{pH}$, temperature and metal ions}

Enzyme activity showed parabolic dependence on $\mathrm{pH}$, with an optimum $\mathrm{pH}$ of 7.4. The enzyme activity was unaffected even at a high temperature of $80^{\circ} \mathrm{C}$. Heavy metal ions such as $\mathrm{Cu}, \mathrm{Cd}, \mathrm{Zn}, \mathrm{Co}, \mathrm{Pb}, \mathrm{Ni}, \mathrm{Hg}$, arsenite and melarsoprol completely inhibited enzyme activity (Table 2).

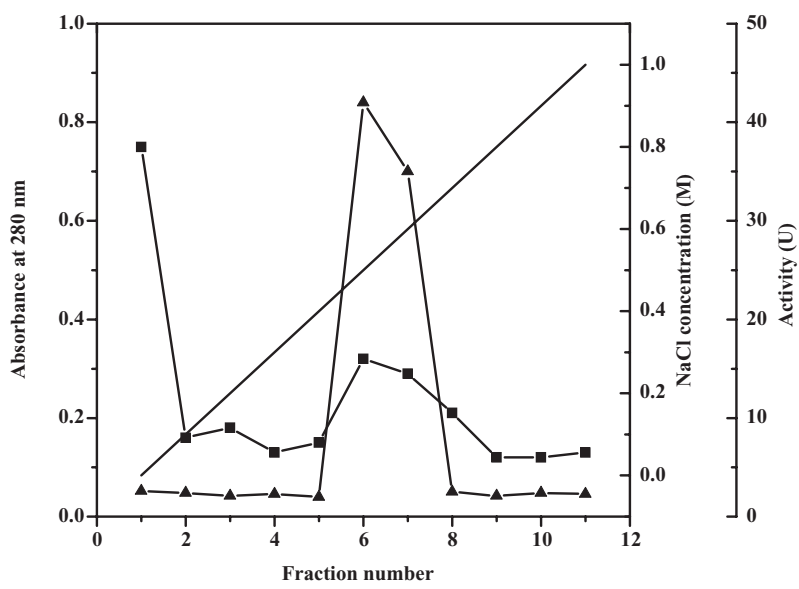

Figure 2 Elution profile for the protein and dihydrolipoamide dehydrogenase activity on CM-Sephadex column. Protein $(\square$ ), enzyme activity $(\mathbf{\Delta}), \mathrm{NaCl}$ concentration (-)

Table 1 Purification of dihydrolipoamide dehydrogenase from mitochondria of $\mathrm{H}$. armigera

\begin{tabular}{|c|c|c|c|c|c|c|}
\hline & Volume (ml) & $\begin{array}{l}\text { Total protein } \\
\qquad(\mathrm{mg})^{\dagger}\end{array}$ & $\begin{array}{c}\text { Total activity } \\
(\mathrm{U})^{\dagger}\end{array}$ & $\begin{array}{l}\text { Specific activity } \\
\qquad(\mathrm{U} / \mathrm{mg})^{\dagger}\end{array}$ & Purification fold & Yield (\%) \\
\hline Crude extract & 50 & $1100 \pm 5.25$ & $1146.30 \pm 10.12$ & $1.04 \pm 0.02$ & 1.00 & 100.00 \\
\hline $\mathrm{NH}_{4} \mathrm{SO}_{4}$ precipitation & 16 & $192 \pm 2.89$ & $867.84 \pm 5.78$ & $4.52 \pm 0.43$ & 4.34 & 75.70 \\
\hline Hydroxylapatite & 6 & $48 \pm 1.54$ & $404.16 \pm 2.87$ & $8.42 \pm 0.77$ & 8.09 & 35.25 \\
\hline CM-Sephadex & 2.5 & $4 \pm 0.19$ & $120.80 \pm 1.99$ & $18.70 \pm 1.22$ & 17.98 & 10.53 \\
\hline
\end{tabular}

${ }^{\dagger}$ Values in the table represents Mean $\pm \operatorname{SE}(n=3)$ 


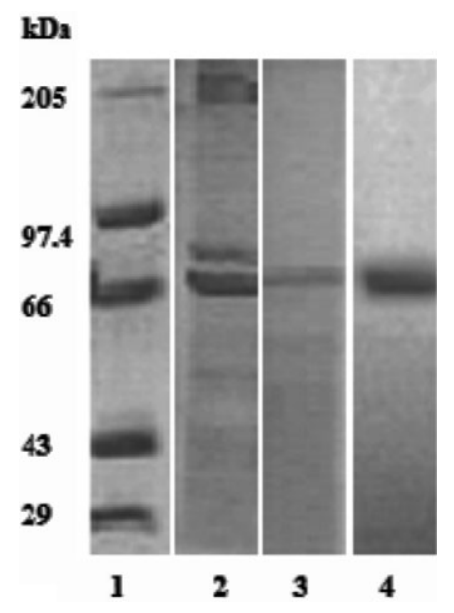

Figure 3 Sodium dodecylsulfate polyacrylamide gel electrophoresis pattern of dihydrolipoamide dehydrogenase of $\mathrm{H}$. armigera. The proteins were detected by Coomassie blue. Lane 1, molecular weight markers (29-205 kDa); lane 2, 3[(3-cholamidopropyl) dimethylammonio]-propanesulfonic acid solublized mitochondrial pellet; lane 3, purified enzyme (CM-Sephadex fraction); lane 4, gel stained for the activity of the enzyme (staining procedure mentioned in text).

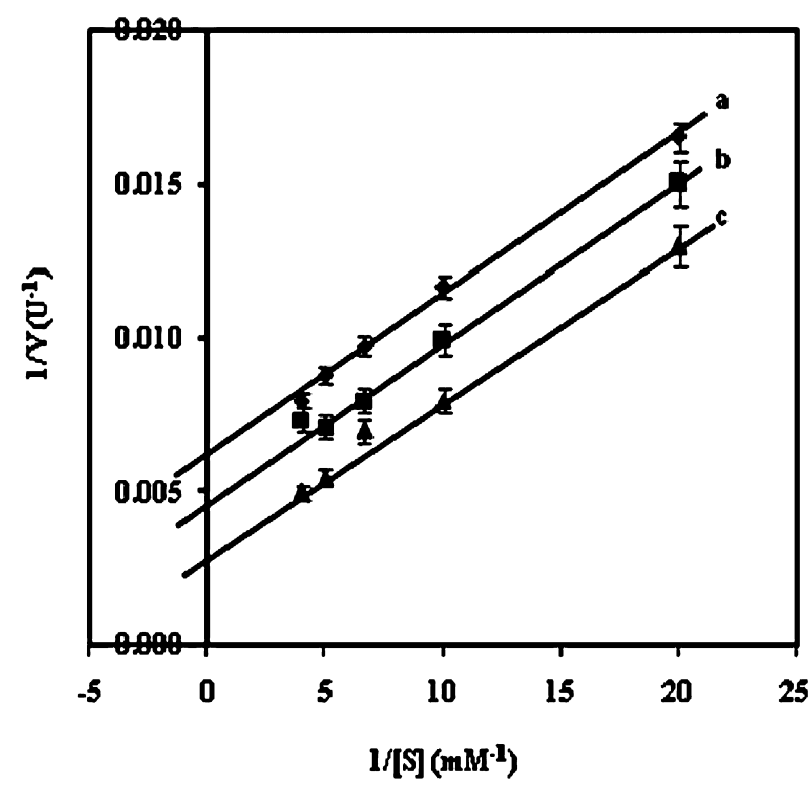

Figure 4 Double reciprocal plots for the initial velocity of the enzyme with varying concentrations of $\mathrm{NADH}$ at fixed concentrations of lipoamide, $1 \mathrm{mmol} / \mathrm{L}$ (a), $1.5 \mathrm{mmol} / \mathrm{L}$ (b) and $2 \mathrm{mmol} / \mathrm{L}$ (c), in $50 \mathrm{mmol} / \mathrm{L}$ phosphate buffer, $\mathrm{pH} 7.4$, containing $1 \mathrm{mmol} / \mathrm{L}$ ethylendiametetraacetic acid and $1 \mathrm{mmol} / \mathrm{L}$ dithioerythritol.

\section{Identification of coenzyme}

The spectra of DHLDH showed absorption maxima at $420 \mathrm{~nm}, 455 \mathrm{~nm}$ and $475 \mathrm{~nm}$ (Fig. 5). The absorbance at $455 \mathrm{~nm}$ decreased when the enzyme was reduced with
Table 2 Effect of metal ions on dihydrolipoamide dehydrogenase activity of $H$. armigera

\begin{tabular}{lc}
\hline Metal $(1 \mathrm{mmol} / \mathrm{L})$ & Activity $(\%)^{\dagger}$ \\
\hline Control & 100.00 \\
$\mathrm{CaCl}_{2}$ & 156.67 \\
$\mathrm{KCl}$ & 153.34 \\
$\mathrm{NaCl}$ & 113.33 \\
$\mathrm{MgCl}_{2}$ & 106.67 \\
$\mathrm{MnCl}_{2}$ & 106.67 \\
$\mathrm{FeSO}_{4}$ & 90.00 \\
$\mathrm{AgNO}_{3}$ & 33.33 \\
$\mathrm{FeCl}_{3}$ & 20.00 \\
$\mathrm{CuSO}_{4}$ & 3.76 \\
$\mathrm{PbSO}_{4}$ & 3.79 \\
$\mathrm{ZnSO}_{4}$ & 3.72 \\
$\mathrm{CdCl}_{2}$ & 3.72 \\
$\mathrm{HgCl}_{2}$ & 4.09 \\
$\mathrm{CoCl}_{2}$ & 3.76 \\
$\mathrm{Sodium}_{2}$ arsenite & 3.79 \\
$\mathrm{Melarsoprol}$ & 3.45 \\
\hline
\end{tabular}

${ }^{+}$The values are means of three different assays.

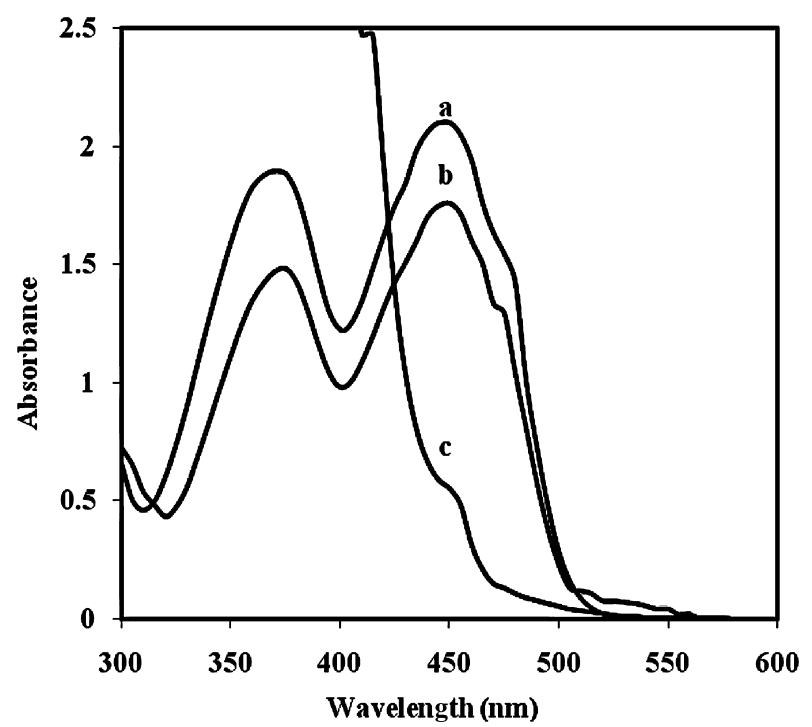

Figure 5 Absorption spectra of dihydrolipoamide dehydrogenase of $H$. armigera. The oxidized enzyme in $50 \mathrm{mmol} / \mathrm{L}$ phosphate buffer, $\mathrm{pH} 7.4$ (a) was reduced with $2 \mathrm{mmol} / \mathrm{L} \mathrm{NADH}$ (b) and excess sodium dithionite (c).

$2 \mathrm{mmol} / \mathrm{L}$ NADH. Addition of sodium dithionite resulted in complete decrease of absorbance at $455 \mathrm{~nm}$. These types of spectra are typical of flavoproteins (Lohrer \& Krauth-Siegel 1990).

\section{N-terminal sequence of DHLDH}

Figure 6 shows the alignment of $\mathrm{N}$-terminal sequence of Ha-DHLDH with different organisms, and about ten 
1MQKFDVVVIGAGPGGY16......H. armigera

39 DIVVIGSGPGGY50..... D. melanogaster (GI: 7293932)

32 DLVVIGAGPGGY43........ sexta (GI: 2267131)

33 DLVVIGSGPGGY44_........ mori (GI: 112983096)

13 DVVVIGGGPGGY24......T. cruzi (GI: 6166121)

43 DVTVIGSGPGGY54........Human (GI: 1339989)

43 DVTVIGSGPGGY54...... Bovine (GI: 296488519)

43 DVTVIGSGPGGY54........Pig

(GI: 262072947)

7 DVVII GGGPAGY16.......Yeast

(GI: 15826395)

1MQKFDVVVLGAGPGGY16........ mycoides (GI: 256385283)

Figure 6 Alignment of the N-terminal sequence of $H$. armigera dihydrolipoamide dehydrogenase (DHLDH) with DHLDHs of Drosophila melanogaster, Manduca sexta, Bombyx mori, Trypanosoma cruzi, human, bovine, pig, yeast, and Mycoplasma mycoides.

positions were found to be identical with the sequence of mammalian and arthropod DHLDH. The sequence of DHLDH of $H$. armigera showed homology with the oxidoreductase region of mammal's DHLDH (Otulakowski \& Robinson 1987) and the stretch of sequence GAGPGG represented the binding site for the pyrophosphate group of FAD (Lohrer \& Krauth-Siegel 1990).

\section{Discussion}

The present study describes the isolation of DHLDH from the mitochondria of $H$. armigera. Apart from its role in metabolism in association with ketoacids dehydrogenase complexes, DHLDH is also involved in reducing intracellular thiol groups. It has also been reported that, in mitochondria, dihydrolipoic acid plays an important role in maintaining the Adenosine triphosphate (ATP) content in the cell, that is, they enhance the ATP synthase activity and prevent ATPase activation (Zimmer et al. 1991) and also maintain the membrane proteins in proper redox state (Serrano 1992).

DHLDH from $H$. armigera was found to be specific to NADH and no lipoamide-dependent NADPH oxidation was detected. Based on substrate specificity, Dietrichs and Andreesen (1990) classified DHLDH into four types: one utilizing NADH alone, the second utilizing both NADH and NADPH, the third utilizing NADPH alone and the fourth utilizing both NADH and NADPH with preference for NADPH. The DHLDH isolated from $H$. armigera thus represents the classical type of enzyme utilizing only NADH as its substrate, having a relative molecular weight (Mr) of
$66 \mathrm{kDa}$ per subunit. The native molecular weight of the protein was found to be $128 \mathrm{kDa}$, suggesting that the protein existed as a homodimer in association with ketoacid dehydrogenase complexes. The molecular weight of the enzyme reported from Trypanosoma cruzi (Lohrer \& Krauth-Siegel 1990), Manduca sexta (Pullikuth \& Gill 1997) and human liver (Ide et al. 1967), have a subunit Mr of $55 \mathrm{kDa}, 51 \mathrm{kDa}$ and $138 \mathrm{kDa}$ (native molecular weight), respectively, which are around the Mr of DHLDH of $H$. armigera. The enzyme also reduces 2,6-dichloroindophenol and potassium ferricyanide using NADH as a physiological electron donor. DHLDH is known for its broader specificity for artificial electron acceptors (Youn et al. 1998).

The enzyme showed a parabolic dependence on $\mathrm{pH}$ of the medium, with an optimum $\mathrm{pH}$ of 7.4. In alkaline conditions, the enzyme activity gradually decreased due to denaturation of the enzyme. Optimum $\mathrm{pH}$ for DHLDH from T. cruzi is 6.75 , and human liver 6.5 , which is around neutral $\mathrm{pH}$. The enzyme was resistant to thermal inactivation and enzyme activity was not affected even at high temperatures up to $80^{\circ} \mathrm{C}$. According to Schmincke-ott and Bisswanger (1981), the transition state activation energy is $43 \mathrm{~kJ} / \mathrm{mol}$ for the complex bound form and $74.8 \mathrm{~kJ} / \mathrm{mol}$ for the individual $\mathrm{E} 3$ component in E. coli K12 strain. This reflects the stability of the component and its ability to withstand such high temperatures to overcome the transition state barrier.

$\mathrm{K}_{\mathrm{m}}$ for the substrates, lipoamide and NADH were $0.4 \mathrm{mmol} / \mathrm{L}$ and $0.083 \mathrm{mmol} / \mathrm{L}$, respectively. These values are similar for the substrates from other organisms, for example, $\mathrm{K}_{\mathrm{m}}$ for NADH with human liver (Ide et al. 1967) and T. cruzi (Lohrer \& Krauth-Siegel 1990) DHLDH is $0.023 \mathrm{mmol} / \mathrm{L}$ and $1.33 \mathrm{mmol} / \mathrm{L}$, respectively, while a high $\mathrm{K}_{\mathrm{m}}$ of $5 \mathrm{mmol} / \mathrm{L}$ has been reported for lipoamide with DHLDH of T. cruzi (Lohrer \& Krauth-Siegel 1990) and bovine liver mitochondria (Lusty 1963). A series of parallel lines were obtained when a double reciprocal plot was drawn (Fig. 4). Such behavior is exhibited by enzymes operated by a ping-pong mechanism, as proposed in some bacteria (Youn et al. 1998) and in eukaryotes (Massey et al. 1960; Reed 1973). This also implied that NADH and disulfide substrate have different binding sites on the enzyme. The spectral properties found with DHLDH of $H$. armigera are in accordance with those of DHLDH of T. cruzi (Lohrer \& KrauthSiegel 1990) and pig (Massey et al. 1960). Metal ions such as $\mathrm{Cu}, \mathrm{Cd}, \mathrm{Zn}, \mathrm{Co}, \mathrm{Pb}, \mathrm{Ni}, \mathrm{Hg}$, arsenite and melarsoprol completely inhibited enzyme activity, whereas $\mathrm{Ca}$ and $\mathrm{K}$ enhanced enzyme activity up to $50 \%$ (Table 2 ).

The N-terminal sequence of Ha-DHLDH was identical to bacterial, arthropod and mammalian DHLDH. The sequence lies in FAD binding domain of the enzyme, which is highly conserved, as observed in the E3 component of M. sexta (Pullikuth \& Gill 1997) and T. cruzi (Lohrer \& Krauth-Siegel 1990). The enzyme also showed homology to the conserved 
sequence of human erythrocyte glutathione reductase (Thieme et al. 1981), and Pseudomonas aeruginosa mercury (II) reductase (Brown et al. 1983). Evidence has shown that DHLDH present in cytoplasmic membranes of T. brucei (Danson et al. 1987) and lpd mutant E. coli (Richarme 1989) are not a component of ketoacid dehydrogenase but are meant for uptake of monosaccharides in the cell. Such a cytoplasmic localization of the enzyme in H. armigera was not observed in the present study. Biochemical documentation of the catalytic properties and the behavior of the multienzyme complexes are necessary to understand their role in metabolism. These studies will help to link evolutionary relationships. Arsenical drugs such as melarsoprol (Friedheim 1994) and melarsen oxide (Fairlamb et al. 1992; Milord et al. 1992) have been used for the treatment of African trypanosomiasis caused by trypanosome. These drugs mainly target oxidoreductase enzymes such as trypanothione reductase and lipoamide dehydrogenase. In the present study we observed that some of the arsenical compounds are potent inhibitors of Ha-DHLDH (Table 2). Therefore, it will be interesting to synthesize similar arsenical compounds targeting metabolic enzymes for the control of phytophagous insect pests such as $H$. armigera, since this insect has developed a high level of resistance to commonly used insecticides.

\section{Acknowledgement}

This work was supported by the University of Agricultural Sciences, New Delhi, India, providing a junior research fellowship under the scheme "Research Fellowship in Science for Meritorious Students” (RFSMS).

\section{References}

Babady NE, Pang YP, Elpeleg O, Isaya G (2007) Cryptic proteolytic activity of dihydrolipoamide dehydrogenase. Proceedings of the National Academy of Sciences of the United States of America 104: 6158-6163.

Brautigam CA, Chuan JL, Tomchick DR, Machius M, Chuang DT (2005) Crystal structure of human dihydrolipoamide dehydrogenase: $\mathrm{NAD}^{+} / \mathrm{NADH}$ binding and the structural basis of disease-causing mutations. Journal of Molecular Biology 350: 543-552.

Brown NL, Ford SJ, Pridmore RD, Fritzinger DC (1983) Nucleotide sequence of a gene from the Pseudomonas transposon Tn50Z encoding mercuric reductase. Biochemistry 22: 4089 4095.

Chaturvedi I (2007) Status of insecticide resistance in the cotton bollworm, Helicoverpa armigera (Hubner). Journal of Central European Agriculture 8 (2): 171-182.

Danson MJ, Conroy K, McQuattie A, Stevenson JK (1987) Dihydrolipoamide dehydrogenase from Trypanosoma brucei. Characterization and cellular location. Biochemistry Journal 243: 661-665.
Dietrichs D, Andreesen JR (1990) Purification and comparative studies of dihydrolipoamide dehydrogenase from the anaerobic, glycine-utilizing bacteria Peptostreptococcus glycinophilus, Clostridium cylindrosporum, and Clostridium sporogenes. Journal of Bacteriology 172: 243-251.

Fairlamb AH, Smith K, Hunter KJ (1992) The interaction of arsenical drugs with dihydrolipoamide dehydrogenase from arsenical resistant and sensitive strains of Trypanosoma brucei brucei. Molecular and Biochemical Parasitology 53: 223-232.

Friedheim EAH (1994) Mel B in the treatment of human trypanosomiasis. American Journal of Tropical Medicine and Hygiene 29: 173-180.

Gunning RV, Dang HT, Kemp FC, Nicholson IC, Moores GD (2005) New resistance mechanism in Helicoverpa armigera threatens transgenic crops expressing Bacillus thuringiensis Cry1Ac toxin. Applied and Environmental Microbiology $\mathbf{7 1}$ (5): 2558-2563.

Hein S, Steinbüchel A (1994) Biochemical and molecular characterization of the Alcaligenes eutrophus pyruvate dehydrogenase complex and identification of a new type of dihydrolipoamide dehydrogenase. Journal of Bacteriology 176: 4394-4408.

Huo J, Shi H, Yao Q, Chen H, Wang L, Chen K (2010) Cloning and purification of recombinant silkworm dihydrolipoamide dehydrogenase expressed in Escherichia coli. Protein Expression and Purification 72: 95-100.

Ide S, Hayakawa T, Okabe K, Koike M (1967) Lipoamide dehydrogenase from human liver. Journal of Biological Chemistry 242: 54-60.

Igamberdiev AU, Bykova NV, Ens W, Hill RD (2004) Dihydrolipoamide dehydrogenase from porcine heart catalyzes NADHdependent scavenging of nitric oxide. FEBS Letters 568: 146150.

Korotchkina LG, Yang H, Tirosh O, Packer L, Patel MS (2001) Protection by thiols of the mitochondrial complexes from 4-hydroxy-2-nonenal. Free Radical Biology and Medicine 30: 992-999.

Laemmli UK (1970) Cleavage of structural proteins during the assembly of the head of bacteriophage T4. Nature 227: 680 685.

Lohrer H, Krauth-Siegel RL (1990) Purification and characterization of lipoamide dehydrogenase from Trypanosoma cruzi. European Journal of Biochemistry 194: 863-869.

Lowry OH, Rosebrough NI, Farr AL, Randall RJ (1951) Protein measurement with the Folin phenol reagent. Journal of Biological Chemistry 193: 265-275.

Lusty CJ (1963) Lipoyl dehydrogenase from beef liver mitochondria. Journal of Biological Chemistry 238: 3443-3452.

Margolis J, Kenrick KG (1967) Polyacrylamide gel electrophoresis across a molecular sieve gradient. Nature (London) 214 1334-1336.

Massey V, Gibson QH, Veeger C (1960) Intermediates in the catalytic action of lipoyl dehydrogenase (diaphorase). Biochemistry Journal 77: 341-351. 
Milord F, Pepin J, Loko L, Ethier L, Mpia B (1992) Efficacy and toxicity of eflornithine for treatment of Trypanosoma brucei gambiense sleeping sickness. Lancet 340: 652-655.

Novotny V, Basset Y, Miller SE, Weiblen GD, Bremer B, Cizek L et al. (2002) Low host specificity of herbivorous insects in a tropical forest. Nature 416: 841-844.

Otulakowski G, Robinson BH (1987) Isolation and sequence determination of cDNA clones for porcine and human lipoamide dehydrogenase. Homology to other disulfide oxido-reductases. Journal of Biological Chemistry 262: 17313-17318.

Patel MS, Vettakkorumakankav NN, Liu TC (1995) Dihydrolipoamide dehydrogenase: activity assays. Methods in Enzymology 252: 186-195.

Pullikuth AK, Gill SS (1997) Primary structure of an invertebrate dihydrolipoamide dehydrogenase with phylogenetic relationship to vertebrate and bacterial disulfide oxidoreductases. Gene 200: $163-172$.

Rajashankar KR, Bryk R, Kniewel R, Buglino JA, Nathan CF, Lima CD (2005) Crystal structure and functional analysis of lipoamide dehydrogenase from Mycobacterium tuberculosis. Journal of Biological Chemistry 280: 33977-33983.

Reed JK (1973) Studies on the kinetic mechanism of lipoamide dehydrogenase from rat liver mitochondria. Journal of Biological Chemistry 248: 4834-4839.

Richarme G (1989) Purification of a new dihydrolipoamide dehyrogenase from Escherichia coli. Journal of Bacteriology 171: $6580-6585$.
Schmincke-ott E, Bisswanger H (1981) Dihydrolipoamide dehydrogenase component of the pyruvate dehydrogenase from Escherichia coli K12. Comparative characterization of the free and the complex-bound component. European Journal of Biochemistry 114: 413-420.

Serrano A (1992) Purification, characterization and function of dihydrolipoamide dehydrogenase from the cyanobacterium Anabaena sp. Strain P.C.C. 7119. Biochemistry Journal 288 : 823-830.

Sharma HC (2005) Heliothis/Helicoverpa Management "Emerging Trends \& Strategies for Future Research”. Oxford and IBH publishing Co. Pvt. Ltd., New Delhi.

Thieme R, Pai EF, Schirmer RH, Schulz GE (1981) Threedimensional structure of glutathione reductase at $2 \AA$ resolution. Journal of Molecular Biology 152: 763-782.

Yan LJ, Thangthaeng N, Forster MJ (2008) Changes in dihydrolipoamide dehydrogenase and activity during postnatal development and aging in the rat brain. Mechanisms of Ageing and Development 129: 282-290.

Youn H, Kwak J, Youn HD, Hah YC, Kang SO (1998) Lipoamide dehydrogenase from Streptomyces seoulensis: biochemical and genetic properties. Biochimistry and Biophysics Acta 1388: 405-418.

Zimmer G, Mainka L, Kruger E (1991) Dihydrolipoic acid activates oligomycin-sensitive thiol groups and increases ATP synthesis in mitochondria. Archives of Biochemistry and Biophysics 88: 609-613. 